\title{
Prevalence and Correlates of Gambling Disorder Among Secondary School Students in Mbarara Municipality, Uganda.
}

Michael Ugochukwu Anyanwu ( $\square$ mustil4god@gmail.com )

Mbarara University of Science and Technology https://orcid.org/0000-0002-6321-161X

Francis Bajunirwe

Mbarara University of Science and Technology

Imelda Tamwesigire

Mbarara University of Science and Technology

Research article

Keywords: gambling disorder, adolescent gambling, adolescent gambling disorder, student, Mbarara

Posted Date: May 14th, 2020

DOI: https://doi.org/10.21203/rs.3.rs-25227/v1

License: (c) This work is licensed under a Creative Commons Attribution 4.0 International License.

Read Full License 


\section{Abstract \\ Background}

Over the recent years, gambling has evolved and grown substantially with new activities and facilities being introduced, making gambling products and opportunities more available in our environment than ever. While the growth of gambling industry is considered to have a beneficial impact on the economy, it is increasingly becoming a social and public health issue especially among young people leading to gambling disorder, a gambling behavior that damages personal, family, vocational and academic pursuits.

\section{Objectives}

The study determined the prevalence and correlates of gambling disorder among secondary school students in Mbarara Municipality. It also described the gambling activities practiced by students with gambling disorder.

\section{Methods}

A cross sectional study was conducted among secondary school students in Mbarara Municipality in 2019. A total of 921 students, from 12 schools, was recruited using random cluster sampling. Logistic regression models were fitted for factors associated with gambling disorder using STATA 12.

\section{Results}

A total of 921 participants were enrolled in the study, 362 (40\%) reported to have ever gambled and 160 $(17.7 \%)$ were classified as having gambling disorder. The most gambling activity practiced by the students was sports betting. Bivariate analysis shows that age, gender, peer involvement, class of student, type of school, advertisement, phone ownership, substance use, risky sexual behavior and psychological distress were significant when those that had ever gambled but has no gambling disorder was compared to those with gambling disorder. However, male students and those using substances were significant on multivariate analysis.

\section{Conclusion}

This study found a high prevalence of gambling disorder among students. Therefore, there is need to institute public health measures towards raising awareness, prevention and treatment of gambling disorder. 


\section{Background}

The gambling industry has experienced a rapid increase since the year 2000 with new gambling activities and facilities being introduced in Uganda. The increase in gambling activities has been in the participation and diversity of gambling activities. The proliferation of gambling has seen the industry diversify from the early gambling activities such as casino to new activities like sports betting and online betting among other forms (1). In 2014, there were estimated to be over 1000 gambling outlets ranging from sports betting, casino gambling, national lottery/play lotto, slot machines, pool betting, and online betting in Uganda (2).

The gambling industry in Uganda was regulated by the National Lotteries Board (NLB) which was guided by the National Lotteries Act of 1967 and the Gaming and Pool Betting Act of 1968. However, due to the expansion of the gambling industry, with new gambling activities being introduced, and advancement in technology, most of the aspects of lottery and gaming law became out dated (3). Thus, the National Lotteries Board (NLB) was rebranded and redefined to the National Gaming Board (NGB) from February 2018, operating under the Lotteries and Gaming Act of 2016. The NGB was established to guide the conduct of gambling activities, provide for licensing and regulation of gaming and betting activities.

According to the lotteries and gaming Act, a minor is a person who is below 25 years of age, and the Act incriminates accepting payments from a minor or accepting access or entry into a gaming or betting premises. The Act also obliges a betting operator to require an individual to present a national identity card for Ugandan nationals or passport for foreign nationals as proof of age before permitting persons access to gambling premises or to engage in gambling activities, citing of gambling outlets away from schools and universities, hospitals, markets, place of worship or government offices (4). Although these laws are to guard against under age gambling, in practice such laws are rarely implemented and are willfully ignored by the owners of the gambling outlets in Uganda (1).

Prevalence of Gambling Disorder

Gambling has evolved considerably that it is widely available and viewed as an acceptable form of entertainment. In the general population, a meta-analysis of prevalence surveys reported the worldwide prevalence of gambling disorder of about 3 percent (5) while (6) in their systemic review of worldwide prevalence of gambling disorder reported a prevalence between $0.12-5.8$ percent.

In Africa, gambling disorder is scarcely studied. In South Africa, (7), reported that the national prevalence of gambling disorder to be 3 percent, while (8) in their overview, indicated the prevalence of gambling disorder in South Africa is between 4.2 and 6.8 percent. In Uganda, (1) reported 5.7 percent prevalence of gambling disorder in participants aged 18 years old and above in Kampala.

In adolescents and secondary school students, gambling is increasingly becoming one of the most popular leisure activities worldwide, with rates of gambling disorder being higher in adolescents than in adults (9). This is due to adolescents high propensity for risk-taking (10), and being unaware of the 
potential undesirable effects of gambling $(11,12)$. The Prevalence of gambling disorder has been shown to be highest in adolescents and young adults compared to any other population. (13) showed that the prevalence of gambling disorder in adolescents is two to four times higher in adolescents compared to adults in the same population. A study conducted by (14) showed that one-third of high school students in the USA had engaged in gambling activities and 31 percent of the gamblers experience gambling disorder. Also, a study of Finnish adolescents aged between 12 and 15 years, reported that 7.9 percent of students are at risk of having gambling disorder (15). In a meta-analysis of the prevalence surveys of gambling disorder among students from across the world, the mean rate of probable gambling disorder was reported to be 10.2 percent (16) while country-specific rates ranged from 3-32\% in the United States, Canada (8.7\%), Scotland (3.9\%), Japan (4.2\%), Nigeria (14.2\%) and China (6.4\%). In Sub Saharan Africa, which has the world's largest youthful population (17), only a few studies exist in gambling disorder. A study conducted among students in Ethiopia reported that $73 \%$ had ever gambled, out of which about $7 \%$ had gambling disorder (18).

\section{Common Gambling Activities Among Students}

Gambling activities among adolescents differ from that of adults, although adolescents indulge in gambling activities that are also common among adults such as cards, poker, lottery and sports (19). In Uganda, (1) revealed that sports betting, promotional competitions and Ludo were the most frequent gambling activities among adults aged 18 years and above. However, (18) reported that playing cards was the most frequent gambling activity among high school students in Ethiopia, followed by the flipping of coins and pool while internet gambling was among the least gambling activity. (20) in their study of adolescent gambling between the ages of 7 and 12 years, revealed that cards (39.8\%) and bingo/scratches $(40.5 \%)$ were the most frequently reported gambling activities while racing $(32 \%)$ and sporting gambling $26 \%$ were also popular. In another study conducted among high school youths, card or dice (19.4\%) was the most frequently cited gambling activity, followed by sports (11.4\%); and lottery $(8.9 \%)$ (14). Also, (21) showed that lottery was the most popular gambling activity followed by football, cricket and playing cards among college students and gambling activities such as lottery, cards, online and horse gambling were more common among students with gambling disorder.

Sociodemographic Factors Associated with Gambling Disorder

Among the sociodemographic factors associated with gambling disorder, (1) revealed that youths between the ages of 18-30 years, employed and males participate more in gambling and are more likely to have a gambling disorder. Also, a national survey in the U.S. found that gambling increases with age, and gambling disorder was common among adolescents that lived independently from their parents and is higher among Catholic gamblers compared to Protestant gamblers (22). Peers and family members have influence on the gambling behaviors of adolescents. Studies have demonstrated that adolescents first formal contacts with gambling are often their parents or family members $(23,24)$. Parental gambling is associated with higher rates of gambling participation and higher rates of gambling disorder among adolescents (25). Adolescent who believe that their parents gamble are more likely to try gambling 
themselves, and have higher rates of gambling disorder (26). However, in contrast to those individuals who gamble because of involvement of family members, there are individuals whose negative experiences with the psychological, physical and financial toll of gambling among family members or friends led to less gambling or no gambling (27).

\section{Environmental Factors Associated with Gambling Disorder}

Increases in gambling have most often been explained by the availability of gambling activities, and advertising. Studies have shown that the repeated cues to gamble from advertising are especially problematic for people who already have a gambling disorder or are recovering from one (28) and youths who scored high on a vulnerability index reported that they often gamble, after seeing an advertisement (29). Also, (30) revealed in his study that technology plays a role in the development and enhancement of gambling disorder.

\section{School Factors Associated with Gambling Disorder}

A study that evaluated the effect of gambling education reported that the beliefs and behavior of youths aged 12 to 18 years changed immediately after an education program (31). Also, a study with a long term follow-up of twelve months reported that the immediate gains after gambling intervention was maintained (32), however, there is no data on whether these programs reduced the incidence of gambling disorder. Another study reported that gambling class alone as an intervention is insufficient to change students gambling behavior, but when used in conjunction with other programs, it could become an integral component in reducing gambling disorder (33). (34) reported that day students and students in mixed-gender schools participated more in gambling compared to boarding students and single-sex schools. It has been found by studies conducted among students that academic performance is correlated with gambling disorder. Studies show that students with gambling disorder generally have low grades in their academics $(21,35)$.

Health Factors Associated with Gambling Disorder

Studies have found a high occurrence of alcohol and substance use with gambling disorder. A crosssectional questionnaire survey of a stratified, random sample of 4,734 high school students aged 1223 years in Hong Kong showed that gambling significantly correlated with tobacco use and alcohol use (36). Also, college students that gambles were reported to have had a lifetime history of use of alcohol, tobacco and cannabis (37). Studies have found correlations between gambling disorder and self-reported mental health such as anxiety (38), depression (39) and obsession (40). It has been noted that depressive disorder is significantly higher among individuals who are gamblers compared with the overall population $(41,42)$. Also, $(43)$ reported that gamblers are more likely to engage in risky sexual behaviors compared to non-gamblers.

Gambling is gradually emerging as a social and public health problem worldwide (44). In Uganda, the media is rift with advertisements for gambling mostly sports-related and this may raise public health 
concerns as adolescents and young adults engage in sports activities and may be a soft target. Though studies have shown that adolescents have the highest prevalence of gambling disorder of any population and that the prevalence of gambling disorder in adolescents is two to four times higher compared to that of adults, yet no study on gambling disorder exist in Uganda among adolescents. The results of this research will not only provide data on gambling disorder among adolescents in Uganda but will also provide a basis for similar studies on gambling disorder among adolescents to be carried. It will guide policy-makers in designing effective preventive, regulatory and treatment programs for gambling disorder, thereby, improving the health and welfare of adolescents. This study determined the prevalence of gambling disorder and described common gambling activities practised among students with gambling disorder. It further identified the sociodemographic, school, environmental and health factors associated with gambling disorder.

\section{Methods}

\section{Participants and Procedure}

A cross-sectional study was conducted among secondary school students in Mbarara Municipality Uganda, in 2019. There were about 35 secondary schools with a total enrollment of 11,106 students in the municipality $(45,46)$. A list of schools in Mbarara Municipality was obtained from Mbarara Municipal Education Office and a total of 921 students from 12 schools were randomly selected using multi-stage cluster random sampling. Due to sampling of students from different schools, adjustments were made for the clustering effect of schools with an intra cluster correlation (how much students from the same school are related in terms of gambling), ICC of 0.014 . Each division in Mbarara Municipality was represented by one public and one private school. At each school, at least 60 students were randomly selected with 10 students from each class using the class register. The study recruited students that had spent at least two months or one term in the school.

A self-administered questionnaire was used to collect data. Research assistants that had been trained, administered the paper and pencil questionnaire. They explained the objectives of the study to the students and assured them that all information was anonymous, no right or wrong answer and that answers would not affect their grades in any way. The questionnaire was administered to students that consented to the study. No incentive was given for participating in the study.

\section{Ethical Considerations}

Ethical approval was received from the Faculty of Medicine Research Committee and the Research Ethics Committee of Mbarara University of Science and Technology. Permission was sought, administrative clearance and authorization to carry out the study were obtained from the various secondary schools. Written informed consent was obtained from students aged 18 years and above while written informed assent was obtained from students below 18 years and school administrators. The objective of the study and confidentiality was explained to school administrators and students. The decision of students who were not willing to participate was respected. 
Measures

Sociodemographic factors such as age, gender, religion, residence and participation on gambling activities were assessed by a self-reported questionnaire.

\section{Gambling Disorder}

This was measured based on the Diagnostic and Statistical Manual of Mental Health Fourth Version Adapted for Juveniles Multiple Response (DSM-IV-MR-J) scores. The DSM-IV-MR-J instrument has been shown to be reliable and valid among young people with a Cronbach's alpha value of 0.75 (47). A score of $0-3$ was classified as "no gambling disorder" and a score of 4 and above classified as "gambling disorder" (48).

Substance Use

Substance use among the students was assessed by alcohol, smoking and substance involvement screening test (ASSIST), a tool validated by World Health Organization for assessing the use of alcohol, tobacco products and other drugs. Substance use was assessed using the second question from ASSIST (49). It consists of 10 questions assessing substance use in the past three months, with Never $=0$, Once/twice $=2$, Monthly $=3$, Weekly $=4$, and Daily $=5$. A score of " 0 " was classified as "no use" and 2 and above classified as "substance use".

Psychological Distress

Psychological distress was assessed with Kessler's psychological distress scale (K10), a ten-item with a 5 point Likert scale that evaluates the frequency of depressive and anxiety symptoms over the past four weeks. Psychological distress was categorized into normal, mild, and severe. Scores range from 10-50, with a score of 0-19 categorized as normal, 20-24 as mild distress, and 25-50 as severe psychological distress (50).

Risky Sexual Behavior

Risky sexual behavior was assessed with questions on being sexually active, use of contraceptive and pregnancy. It was categorized into two: "No risky behavior" and "Risky Sexual behavior". Any student that answered "No" to being sexually active or "Yes" to being sexually active but "No" to her or their sexual partner ever being pregnant and "Yes" to contraceptive use were categorized as "No risky sexual behavior"

\section{Statistical Analyses}

Data collected from the questionnaires was inspected for errors and gaps. After inspection and editing, the questions were coded, entered and analyzed using STATA 12, and incomplete questionnaires on gambling behavior were excluded. The prevalence of gambling disorder was obtained from the percentage of students that scored 4 and above on the DSM-IV-MR-J tool. Frequencies and cross- 
tabulation were used to describe gambling activities. Logistic regression analysis was used to determine the association between gambling disorder and the correlates. All the variables with a $p$ value of $\leq 0.001$ were included in the multivariate logistic regression model. A $p$ value of $<0.05$ was used to determine the statistical significance at $95 \%$ confidence interval.

\section{Results}

Socio-demographic Characteristics of Students

Out of the 921 questionnaires returned, 905 questionnaires were included in the analyses and 16 questionnaires were excluded as they were returned incomplete and had missing information on gambling.

Table 1 shows the sociodemographic characteristics of the respondents. The participants had a mean age of $16.9 \pm 2.2$ years, and $59.2 \%$ were aged below 18 years. While $55.1 \%$ of participants aged below 18 years had ever gambled, however, a higher percentage of students aged 18 years and above had gambling disorder. $53.8 \%$ of the students were male, $64.1 \%$ and $74 \%$ of the male students had ever gambled and had gambling disorder, respectively. About $22 \%$ of the students were in S4 class, majority of the students were boarding student $75.9 \%$, and $86.6 \%$ in mixed schools. Most of the students were living with their parents $91.6 \%$, and $37.1 \%$ belonged to the Catholic faith. 
Table 1

Sociodemographic Characteristics of Participants

\begin{tabular}{|c|c|c|c|}
\hline Variable & $\begin{array}{l}\text { Total Participant } \\
(\mathrm{N}=905) \\
\mathrm{N}(\%)\end{array}$ & $\begin{array}{l}\text { Ever Gambled } \\
(\mathrm{N}=362) \\
\mathrm{n}(\%)\end{array}$ & $\begin{array}{l}\text { Gambling disorder } \\
(\mathrm{N}=160) \\
\mathrm{n}(\%)\end{array}$ \\
\hline Age Categories & $481(59.2)$ & $178(55.1)$ & $59(43.1)$ \\
\hline $\begin{array}{l}\text { Below } 18 \text { years } \\
18 \text { years and above }\end{array}$ & $332(40.8)$ & $145(44.9)$ & 78 (56.9) \\
\hline Gender & $484(53.8)$ & $230(64.1)$ & $117(74.0)$ \\
\hline $\begin{array}{l}\text { Male } \\
\text { Female }\end{array}$ & $415(46.2)$ & $129(35.9)$ & $41(26.0)$ \\
\hline Class & 125 (13.9) & $43(11.9)$ & $16(10.0)$ \\
\hline S1 & $129(14.3)$ & $60(16.6)$ & $21(13.1)$ \\
\hline S2 & $180(20.0)$ & 70 (19.3) & $26(16.3)$ \\
\hline S3 & $198(22.0)$ & $66(18.2)$ & $30(18.9)$ \\
\hline S4 & 147 (16.3) & $66(18.2)$ & $37(23.1)$ \\
\hline $\begin{array}{l}\text { S5 } \\
\text { S6 }\end{array}$ & $123(13.6)$ & $57(15.7)$ & $30(18.9)$ \\
\hline Type of Student & 673 (75.9) & $273(76.7)$ & $124(80.0)$ \\
\hline $\begin{array}{l}\text { Boarding } \\
\text { Day }\end{array}$ & $214(24.1)$ & $83(23.3)$ & $31(20.0)$ \\
\hline Type of School & $492(54.4)$ & $176(48.6)$ & $81(50.6)$ \\
\hline Private & $413(45.6)$ & $186(51.4)$ & $79(49.4)$ \\
\hline Public & $784(86.6)$ & $307(84.8)$ & $148(92.5)$ \\
\hline $\begin{array}{l}\text { Mixed } \\
\text { Single }\end{array}$ & $121(13.4)$ & $55(15.2)$ & $12(7.5)$ \\
\hline Guardian/Caretaker & $786(91.6)$ & $91(91.0)$ & $140(92.7)$ \\
\hline $\begin{array}{l}\text { Parents } \\
\text { Others }\end{array}$ & $72(8.4)$ & $31(9.0)$ & $11(7.3)$ \\
\hline
\end{tabular}




\begin{tabular}{|llll|}
\hline Variable & $\begin{array}{l}\text { Total Participant } \\
(\mathbf{N}=\mathbf{9 0 5})\end{array}$ & $\begin{array}{l}\text { Ever Gambled } \\
\mathbf{( N = 3 6 2 )}\end{array}$ & $\begin{array}{l}\text { Gambling disorder } \\
\mathbf{( N = 1 6 0 )}\end{array}$ \\
& $\mathbf{N}(\%)$ & $\mathbf{n}(\%)$ & $\mathbf{n}(\%)$ \\
\hline Religion & $333(37.1)$ & $145(40.4)$ & $70(44.0)$ \\
Catholic & $83(9.2)$ & $29(8.1)$ & $12(7.6)$ \\
Moslem & $173(19.3)$ & $62(17.3)$ & $20(12.6)$ \\
Protestant & $196(21.8)$ & $62(17.3)$ & $29(18.2)$ \\
Pentecostal & $113(12.6)$ & $61(17.0)$ & $28(17.6)$ \\
Other & & & $83(56.5)$ \\
\hline Residence & $479(57.3)$ & $194(57.1)$ & $64(43.5)$ \\
Urban/Town & $357(42.7)$ & $146(42.9)$ & \\
Sub-urban & & & \\
\hline
\end{tabular}

Prevalence of Gambling and Gambling Disorder

Participants in the study were grouped into three; never gambled, ever gambled with no disorder and ever gambled with gambling disorder. Out of the 905 students, 362 (40\%) students reported to had ever gambled. Among the students that had ever gambled, $34.7 \%$ reported gambling within the past month (last 30 days), $43 \%$ gambled within the past one year, and $22.3 \%$ reported to had gambled more than one year ago.

Of the total students that participated in this study, 160 (17.7\%) students with a score of 4 and above on the DSM-IV-MR-J, were classified as having gambling disorder. Thus, of the 362 (40\%) students that reported to have ever gambled, $44.2 \%$ have a gambling disorder. Among the 160 students that were classified as having gambling disorder, 55 (34.4\%) students scored four, 58 (36.2\%) scored five, 29 (18.1\%) scored six, 11 (6.9\%) scored seven and 7 (4.4\%) students scored eight on the DSM-IV-MR-J.

Gambling Activities Practiced by Students

Table 2 shows the participation in gambling activities engaged by students. The most common gambling activity practised by students was sports betting 177 (49\%), followed by pool betting 81 (22.4\%) and play station/video games 81 (22.4\%), cards 80 (22.2\%), and flipping of coins $80(22.2 \%)$. Also, the gambling activities that were reported most by those that had gambling disorder was sports betting 109 (68.6\%), followed by pool betting 49 (30.8\%) and flipping of coins 37 (23.3\%). 
Table 2

Participation in Gambling Activities

\begin{tabular}{|lll|}
\hline Gambling Activity & Ever Gambled & Gambling Disorder \\
& $\mathbf{n}(\%)$ & $\mathbf{n}(\%)$ \\
\hline Sports betting & $177(49.0)$ & $109(68.6)$ \\
\hline Pool betting & $81(22.4)$ & $49(30.8)$ \\
\hline Flipping coins & $80(22.2)$ & $37(23.3)$ \\
\hline Play station/video games & $81(22.4)$ & $36(22.6)$ \\
\hline Card/poker & $80(22.2)$ & $34(21.4)$ \\
\hline Betting on animals & $44(12.2)$ & $30(18.9)$ \\
\hline Ludo & $47(13.0)$ & $26(16.4)$ \\
\hline Board games & $50(13.9)$ & $24(15.1)$ \\
\hline Internet/online & $43(11.9)$ & $22(13.8)$ \\
\hline Promotional competitions & $60(16.6)$ & $21(13.2)$ \\
\hline Dice & $33(9.1)$ & $16(10.1)$ \\
\hline Slot machines & $31(8.6)$ & $12(7.6)$ \\
\hline Electronic games & $30(8.3)$ & $12(7.6)$ \\
\hline Casino & $16(4.4)$ & $10(6.3)$ \\
\hline Bingo & $4(1.11)$ & $3(1.9)$ \\
\hline Others & $7(1.9)$ & $2(1.3)$ \\
\hline National lottery/play lotto & $3(0.8)$ & $1(0.6)$ \\
\hline
\end{tabular}

Table 3 shows the trends in gambling activities among students that had ever gambled. Participation in all gambling activities increased over the years with sports betting increasing in the number of participants from $28(15.9 \%)$ to $148(84.1 \%)$, pool betting $11(14.9 \%)$ to $63(85.1 \%)$ and flipping coins from $15(20 \%)$ to $60(80 \%)$. 
Table 3

Trends in gambling participation

\begin{tabular}{|lll|}
\hline Gambling Activities & $\begin{array}{l}\text { Last gambled within the past } \\
\text { year } \\
\mathbf{n}(\%)\end{array}$ & $\begin{array}{l}\text { Last gambled more than one year } \\
\text { ago } \\
\mathbf{n}(\%)\end{array}$ \\
\hline Sports betting & $148(84.1)$ & $28(15.9)$ \\
\hline Pool betting & $63(85.1)$ & $11(14.9)$ \\
\hline Flipping coins & $60(80.0)$ & $15(20.0)$ \\
\hline $\begin{array}{l}\text { Play station/video } \\
\text { games }\end{array}$ & $57(79.2)$ & $15(20.8)$ \\
\hline Card/poker & $54(74.0)$ & $19(26.0)$ \\
\hline Betting on animals & $40(93.0)$ & $3(7.0)$ \\
\hline Ludo & $33(78.6)$ & $9(21.4)$ \\
\hline Board games & $37(80.4)$ & $9(19.6)$ \\
\hline Internet/online & $32(80.0)$ & $8(20.0)$ \\
\hline $\begin{array}{l}\text { Promotional } \\
\text { competitions }\end{array}$ & $49(87.5)$ & $7(12.5)$ \\
\hline Dice & $27(84.4)$ & $5(15.6)$ \\
\hline Slot machines & $21(75.0)$ & $7(25.0)$ \\
\hline Electronic games & $19(73.1)$ & $7(26.9)$ \\
\hline Casino & $13(92.9)$ & $1(7.1)$ \\
\hline Bingo & $4(100.0)$ & $0(0.0)$ \\
\hline Others & $6(85.7)$ & $1(14.3)$ \\
\hline $\begin{array}{l}\text { National lottery/play } \\
\text { lotto }\end{array}$ & $3(100.0)$ & \\
\hline & & \\
\hline
\end{tabular}

Correlates of Gambling and Gambling Disorder

Bivariate analysis in Table 4, 5, and 6 shows the sociodemographic, school, environmental, and health correlates of gambling and gambling disorder.

The sociodemographic factors that were significant when gamblers were compared to non-gamblers includes gender, having part-time job/paid work, parental involvement, peer involvement in gambling, and societal perception on gambling. However, when those that had ever gambled with no disorder was 
compared to those with gambling disorder, age, gender, and peer participation in gambling activities were significant (Table 4). 
Table 4

Sociodemographic Variables Associated with Gambling and Gambling Disorder

\begin{tabular}{|c|c|c|c|c|}
\hline \multirow[t]{2}{*}{ Variable } & \multicolumn{2}{|c|}{$\begin{array}{l}\text { Gambling } \\
\text { (Ever gambled + Never } \\
\text { Gambled) }\end{array}$} & \multicolumn{2}{|c|}{$\begin{array}{l}\text { Gambling disorder } \\
\text { (Ever gambled but no disorder + have } \\
\text { gambling disorder) }\end{array}$} \\
\hline & OR $(95 \% \mathrm{Cl})$ & $\begin{array}{l}P \\
\text { value }\end{array}$ & OR (95\%Cl) & $P$ value \\
\hline Age Categories & 1 & 0.056 & 1 & $<0.001$ \\
\hline $\begin{array}{l}\text { Below } 18 \text { years } \\
18 \text { years and above }\end{array}$ & $\begin{array}{l}1.32(0.99- \\
1.76)\end{array}$ & & $2.35(1.49-3.69)$ & \\
\hline $\begin{array}{l}\text { Gender } \\
\text { Female } \\
\text { Male }\end{array}$ & $\begin{array}{l}1 \\
2.01(1.53- \\
2.64)\end{array}$ & $<.001$ & $\begin{array}{l}1 \\
2.22(1.41-3.49)\end{array}$ & 0.001 \\
\hline $\begin{array}{l}\text { Residence } \\
\text { Urban/Town } \\
\text { Sub-urban }\end{array}$ & $\begin{array}{l}1 \\
1.02(0.77- \\
1.34)\end{array}$ & 0.908 & $\begin{array}{l}1 \\
1.04(0.68-1.61)\end{array}$ & 0.846 \\
\hline $\begin{array}{l}\text { Religion } \\
\text { Catholic } \\
\text { Moslem } \\
\text { Protestant } \\
\text { Pentecostal } \\
\text { Other }\end{array}$ & $\begin{array}{l}1.67(1.15- \\
2.42) \\
1.16(0.67- \\
1.99) \\
1.21(0.78- \\
1.86) \\
1 \\
2.54(1.57- \\
4.08)\end{array}$ & 0.117 & $\begin{array}{l}1.96(1.05-3.66) \\
1.48(0.59-3.69) \\
1 \\
1.85(0.89-3.83) \\
1.78(0.86-3.71)\end{array}$ & 0.649 \\
\hline $\begin{array}{l}\text { Guardian/Caretaker } \\
\text { Parents } \\
\text { Others }\end{array}$ & $\begin{array}{l}1 \\
1.13(0.69- \\
1.84)\end{array}$ & 0.622 & $\begin{array}{l}1.45(0.67-3.14) \\
1\end{array}$ & 0.339 \\
\hline Orphan Status & 1 & 0.109 & $1.07(0.33-3.45)$ & 0.358 \\
\hline $\begin{array}{l}\text { Both Parent Alive } \\
\text { Single Orphan } \\
\text { Double Orphan }\end{array}$ & $\begin{array}{l}1.37(0.94- \\
1.98) \\
1.04(0.49- \\
2.20)\end{array}$ & & $\begin{array}{l}1.40(0.40-4.89) \\
1\end{array}$ & \\
\hline
\end{tabular}




\begin{tabular}{|c|c|c|c|c|}
\hline \multirow[t]{2}{*}{ Variable } & \multicolumn{2}{|c|}{$\begin{array}{l}\text { Gambling } \\
\text { (Ever gambled + Never } \\
\text { Gambled) }\end{array}$} & \multicolumn{2}{|c|}{$\begin{array}{l}\text { Gambling disorder } \\
\text { (Ever gambled but no disorder + have } \\
\text { gambling disorder) }\end{array}$} \\
\hline & OR $(95 \% \mathrm{Cl})$ & $\begin{array}{l}P \\
\text { value }\end{array}$ & OR $(95 \% \mathrm{Cl})$ & $P$ value \\
\hline $\begin{array}{l}\text { Part-Time Job/Paid } \\
\text { Work }\end{array}$ & $\begin{array}{l}1.62(1.08- \\
2.42)\end{array}$ & \multirow[t]{2}{*}{0.020} & \multirow[t]{2}{*}{$\begin{array}{l}1.50(0.85-2.67) \\
1\end{array}$} & \multirow[t]{2}{*}{0.165} \\
\hline $\begin{array}{l}\text { Yes } \\
\text { No }\end{array}$ & 1 & & & \\
\hline Parent Involvement & 1 & \multirow{2}{*}{$<0.001$} & 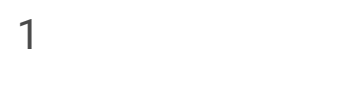 & \multirow[t]{2}{*}{0.942} \\
\hline $\begin{array}{l}\text { No } \\
\text { Yes }\end{array}$ & $\begin{array}{l}2.81(1.96- \\
4.03)\end{array}$ & & $1.02(0.63-1.64)$ & \\
\hline Peer Involvement & 1 & \multirow{2}{*}{$\begin{array}{l}< \\
0.001\end{array}$} & 1 & \multirow[t]{2}{*}{0.014} \\
\hline $\begin{array}{l}\text { No } \\
\text { Yes }\end{array}$ & $\begin{array}{l}5.19(3.57- \\
7.56)\end{array}$ & & $2.55(1.20-5.42)$ & \\
\hline $\begin{array}{l}\text { Societal perception on } \\
\text { gambling }\end{array}$ & $\begin{array}{l}1.66(1.23- \\
2.25)\end{array}$ & \multirow[t]{2}{*}{0.001} & $1.12(0.72-1.76)$ & \multirow[t]{2}{*}{0.610} \\
\hline $\begin{array}{l}\text { Positive } \\
\text { Negative }\end{array}$ & 1 & & 1 & \\
\hline
\end{tabular}

Among the school and environmental factors, type of school (private/public), advertisement and phone ownership were significant when those that had ever gambled was compared to those that had never gambled. Also, when those that had ever gambled but had no disorder was compared to those with gambling disorder, class of student, type of school (mixed/single), advertisement and phone ownership were significant (Table 5). 
Table 5

School and Environmental Variables Associated with Gambling and Gambling Disorder

\begin{tabular}{|c|c|c|c|c|}
\hline \multirow[t]{2}{*}{ Variable } & \multicolumn{2}{|c|}{$\begin{array}{l}\text { Gambling } \\
\text { (Ever gambled + Never } \\
\text { Gambled) }\end{array}$} & \multicolumn{2}{|c|}{$\begin{array}{l}\text { Gambling disorder } \\
\text { (Ever gambled but no disorder + have } \\
\text { gambling disorder) }\end{array}$} \\
\hline & OR $(95 \% \mathrm{Cl})$ & $\begin{array}{l}P \\
\text { value }\end{array}$ & OR $(95 \% \mathrm{Cl})$ & $P$ value \\
\hline \multirow{6}{*}{$\begin{array}{l}\text { Class } \\
\text { S1 } \\
\text { S2 }\end{array}$} & $\begin{array}{l}1.05(0.65- \\
1.68)\end{array}$ & \multirow[t]{6}{*}{0.205} & $1.10(0.487-2.49)$ & \multirow[t]{6}{*}{0.006} \\
\hline & $\begin{array}{l}1.74(1.10- \\
2.74)\end{array}$ & & $1.10(0.54-2.25)$ & \\
\hline & \multirow{2}{*}{$\begin{array}{l}1.27(0.84- \\
1.94)\end{array}$} & & $1.55(0.75-3.17)$ & \\
\hline & & & $2.37(1.15-4.87)$ & \\
\hline & $\begin{array}{l}1 \\
1.63(1.05- \\
2.53)\end{array}$ & & \multirow[t]{2}{*}{$2.06(0.98-4.37)$} & \\
\hline & $\begin{array}{l}1.73(1.09- \\
2.74)\end{array}$ & & & \\
\hline \multirow{2}{*}{$\begin{array}{l}\text { Type of Student } \\
\text { Boarding } \\
\text { Day }\end{array}$} & \multirow{2}{*}{$\begin{array}{l}1.08(0.79- \\
1.48) \\
1\end{array}$} & \multirow[t]{2}{*}{0.644} & & \multirow[t]{2}{*}{0.195} \\
\hline & & & 1 & \\
\hline Type of School & 1 & 0.005 & $1.15(0.76-1.75)$ & 0.497 \\
\hline Private & \multirow{3}{*}{$\begin{array}{l}1.47(1.13- \\
1.92) \\
1 \\
1.30(0.88- \\
1.90)\end{array}$} & \multirow[t]{3}{*}{0.189} & 1 & \multirow[t]{3}{*}{$<0.001$} \\
\hline Public & & & $3.34(1.69-6.57)$ & \\
\hline $\begin{array}{l}\text { Mixed } \\
\text { Single }\end{array}$ & & & 1 & \\
\hline $\begin{array}{l}\text { Taught about gambling } \\
\text { in school }\end{array}$ & 1 & \multirow[t]{2}{*}{0.122} & $1.05(0.59-1.88)$ & \multirow[t]{2}{*}{0.858} \\
\hline $\begin{array}{l}\text { No } \\
\text { Yes }\end{array}$ & $\begin{array}{l}1.33(0.927- \\
1.90)\end{array}$ & & 1 & \\
\hline Ever Failed in a subject & 1 & 0.179 & $1.40(0.83-2.36)$ & 0.207 \\
\hline $\begin{array}{l}\text { No } \\
\text { Yes }\end{array}$ & $\begin{array}{l}1.25(0.90- \\
1.74)\end{array}$ & & 1 & \\
\hline
\end{tabular}




\begin{tabular}{|c|c|c|c|c|}
\hline \multirow[t]{2}{*}{ Variable } & \multicolumn{2}{|c|}{$\begin{array}{l}\text { Gambling } \\
\text { (Ever gambled + Never } \\
\text { Gambled) }\end{array}$} & \multicolumn{2}{|c|}{$\begin{array}{l}\text { Gambling disorder } \\
\text { (Ever gambled but no disorder + have } \\
\text { gambling disorder) }\end{array}$} \\
\hline & OR $(95 \% \mathrm{Cl})$ & $\begin{array}{l}P \\
\text { value }\end{array}$ & OR $(95 \% \mathrm{Cl})$ & $P$ value \\
\hline Advertisement & 1 & \multirow{4}{*}{$\begin{array}{l}<.001 \\
0.001\end{array}$} & 1 & 0.006 \\
\hline Rare & \multirow[t]{2}{*}{$\begin{array}{l}1.30(0.87- \\
1.94)\end{array}$} & & \multirow{3}{*}{$\begin{array}{l}1.94(0.94-3.99) \\
2.59(1.31-5.09)\end{array}$} & \\
\hline Sometimes & & & & \\
\hline Always & $\begin{array}{l}2.19(1.50- \\
3.20)\end{array}$ & & & \\
\hline $\begin{array}{l}\text { Nearest gambling } \\
\text { distance }\end{array}$ & $\begin{array}{l}2.06(1.50- \\
2.82)\end{array}$ & \multirow[t]{3}{*}{0.065} & $1.74(1.04-2.90)$ & 0.090 \\
\hline & $\begin{array}{l}1.77(1.21- \\
2.60)\end{array}$ & & $1.21(0.05-2.24)$ & \\
\hline Above $3 \mathrm{Km}$ & 1 & & & \\
\hline Phone Ownership & 1 & \multirow{2}{*}{$<.001$} & 1 & 0.002 \\
\hline $\begin{array}{l}\text { No } \\
\text { Yes }\end{array}$ & $\begin{array}{l}2.97(2.24- \\
3.93)\end{array}$ & & $2.08(1.29-3.33)$ & \\
\hline
\end{tabular}

Also, among the health variables, students that had ever gambled and those with gambling disorder were more likely to use substances, engage in risky sexual behavior, and have psychological distress compared to those that had never gambled and those with no disorder (Table 6). 
Table 6

Health Variables Associated with Gambling and gambling Disorder

\begin{tabular}{|c|c|c|c|c|}
\hline \multirow[t]{2}{*}{ Variable } & \multicolumn{2}{|c|}{$\begin{array}{l}\text { Gambling } \\
\text { (Ever gambled + Never } \\
\text { Gambled) }\end{array}$} & \multicolumn{2}{|c|}{$\begin{array}{l}\text { Gambling disorder } \\
\text { (Ever gambled but no disorder + have gambling } \\
\text { disorder) }\end{array}$} \\
\hline & OR (95\%Cl) & $P$ value & OR (95\%Cl) & $P$ value \\
\hline Substance Use & 1 & $<0.001$ & 1 & $<0.001$ \\
\hline $\begin{array}{l}\text { No } \\
\text { Yes }\end{array}$ & \multicolumn{2}{|l|}{$\begin{array}{l}2.69(2.03- \\
3.57)\end{array}$} & \multicolumn{2}{|l|}{$2.15(1.41-3.28)$} \\
\hline Risky Sexual & 1 & $<0.001$ & 1 & 0.001 \\
\hline $\begin{array}{l}\text { No } \\
\text { Yes }\end{array}$ & \multicolumn{2}{|l|}{$\begin{array}{l}2.08(1.48- \\
2.92)\end{array}$} & \multicolumn{2}{|l|}{$2.26(1.40-3.66)$} \\
\hline Psychological & 1 & $<0.001$ & 1 & $<0.001$ \\
\hline Normal & \multicolumn{2}{|l|}{$\begin{array}{l}1.51(1.07- \\
2.13)\end{array}$} & \multirow[t]{2}{*}{$\begin{array}{l}1.76(1.01-3.08) \\
2.57(1.55-4.24)\end{array}$} & \\
\hline $\begin{array}{l}\text { Mild } \\
\text { Severe }\end{array}$ & \multicolumn{2}{|l|}{$\begin{array}{l}1.98(1.44- \\
2.71)\end{array}$} & & \\
\hline Chronic Illness & 1 & 0.587 & $1.08(0.67-1.73)$ & 0.748 \\
\hline $\begin{array}{l}\text { No } \\
\text { Yes }\end{array}$ & \multicolumn{2}{|l|}{$\begin{array}{l}1.09(0.80- \\
1.48)\end{array}$} & \multicolumn{2}{|l|}{1} \\
\hline
\end{tabular}

Table 7 shows the multivariate analysis of factors associated with gambling disorder. Male gender (OR: $2.00 ; 1.12-3.43$ ) and substance use (OR: 2.02; 1.23-3.30), were significant when students that ever gambled but had no disorder was compared to students with gambling disorder. 
Table 7

Multivariate Analysis of Variables Associated with Gambling Disorder

\begin{tabular}{|c|c|c|}
\hline \multirow[t]{2}{*}{ Variable } & \multicolumn{2}{|c|}{$\begin{array}{l}\text { Gambling disorder } \\
\text { (Ever gambled but no disorder + gambling disorder) }\end{array}$} \\
\hline & OR $(95 \% \mathrm{Cl})$ & $P$ value \\
\hline Age Categories & 1 & 0.178 \\
\hline $\begin{array}{l}\text { Below } 18 \text { years } \\
18 \text { years and above }\end{array}$ & $1.44(0.85-2.47)$ & \\
\hline Gender & 1 & 0.012 \\
\hline $\begin{array}{l}\text { Female } \\
\text { Male }\end{array}$ & $2.00(1.12-3.43)$ & \\
\hline Type of School & $2.00(0.90-4.39)$ & 0.088 \\
\hline $\begin{array}{l}\text { Mixed } \\
\text { Single }\end{array}$ & 1 & \\
\hline $\begin{array}{l}\text { Substance Use } \\
\text { No } \\
\text { Yes }\end{array}$ & $\begin{array}{l}1 \\
2.02(1.23-3.30)\end{array}$ & 0.005 \\
\hline $\begin{array}{l}\text { Risky Sexual Behavior } \\
\text { No } \\
\text { Yes }\end{array}$ & $\begin{array}{l}1 \\
1.63(0.94-2.85)\end{array}$ & 0.081 \\
\hline Psychological Distress & 1 & 0.954 \\
\hline Normal & $0.98(0.51-1.88)$ & 0.142 \\
\hline $\begin{array}{l}\text { Mild } \\
\text { Severe }\end{array}$ & $1.53(0.87-2.72)$ & \\
\hline
\end{tabular}

\section{Discussion}

The study showed that 40 percent of the participants reported to had ever gambled which is high compared to 24.3 percent reported in a study conducted in Kampala among adults aged 18 years and above (1). However, the prevalence of student that had ever gambled in this study was lower than that found by (18), where 73 percent of students in Ethiopia had ever gambled. Among the participants, 17.7 percent of the students were classified as having gambling disorder in this study using DSM-IV-MR-J. The prevalence of gambling disorder in this study was high in comparison to the study conducted by (1) in 
the adult population which reported 5.7 percent prevalence, however, studies have shown that the prevalence of gambling disorder in adolescents is two to four times higher than the prevalence of adults in the same population (13). Also, the prevalence of gambling disorder among secondary school students reported by (18) was 7 percent which is lower to the prevalence of gambling disorder in this study.

Sports, pool betting and play station /video games were the most gambling activities engaged by students, while those with gambling disorder participated mostly in sports, pool betting and flipping of coins. This study findings is similar to the findings reported in Kampala, where sports betting was reported to be the commonest gambling activity participated by adults (1). This could be as a result of easy accessibility and high proliferation of sports betting outlets, unrestrictive and weak regulatory laws, and growing interest in sports activities. Also, (18) reported that sports betting, playing cards, flipping of coins, pool betting and play station were the most frequent gambling activities among secondary school students. However, (21) showed that lottery was the most popular gambling activity followed by football, cricket and playing cards among college students and those with gambling disorders engage in gambling activities such as lottery, cards, online and horse gambling compared to students with no gambling disorder.

Most of the factors which were significant in bivariate analysis in this study are similar to previous studies. The sociodemographic factors that were associated with gambling are gender, being employed, peer and parental involvement in gambling and societal perception on gambling. However, when those with gambling disorder are compared to those that had ever gambled but had no disorder, age, gender and peer involvement were significant although gender remains significant in the multivariate logistic regression model. Other studies has similar findings where age, gender, and being employed were associated with gambling disorder $(18,21)$. Also, previous studies have shown that parental and peer involvement are associated with higher gambling rates and development of gambling disorder $(25,26$, 51). Also, similar to the findings by (52), communities in which gambling is perceived as normal were more likely to engage in gambling activities.

Type of school was significant in this study which is similar to a study where students in mixed schools are more likely to gamble compared to those in single schools (34). Academic performance and teaching of gambling in schools were not significant in this study contrary to other studies $(21,35)$. Advertisement and technology (mobile phone ownership) were associated with both gambling and gambling disorder which is consistent with previous studies $(28,30)$.

Substance use, psychological distress and risky sexual behavior were associated with gambling and gambling disorder in bivariate logistic regression which is similar to other studies $(21,35,42,43)$, however, on multivariate logistic regression, only substance use was significant in this study.

The strengths of this study include that it is the first study to be conducted on gambling disorder among secondary school students in Uganda. Also, the study included a fairly large number of participants' selected using random cluster sampling with participants from different types of schools and divisions of Mbarara Municipality. The limitations of this study are that the results may not be generalized to the 
larger Ugandan population, as the study was limited to secondary school students in Mbarara Municipality. Also, the study is a cross-sectional study, and the data cannot be used to support directionality or causality between gambling disorder and the various correlates reported.

\section{Conclusion}

The prevalence of gambling disorder is high among secondary school students, and this study finding indicates that more than four out of every ten students that had ever gambled, will have a gambling disorder. Sports betting, pool betting and flipping of coins were the gambling activities practiced most by students with gambling disorder and the increasing availability and accessibility to gambling activities in Uganda will likely lead to an increase in gambling participation and gambling disorder. Gambling disorder was associated with substance use, risky sexual behavior and psychological distress. Thus policy makers should design appropriate interventions for prevention and control of gambling activities in the country, thereby, improving the health and welfare of adolescents in the country.

\section{Declarations}

\section{Ethics approval and consent to participate}

Ethical approval was received from the Faculty of Medicine Research Committee and the Research Ethics Committee of Mbarara University of Science and Technology. Permission was sought, administrative clearance and authorization to carry out the study were obtained from the various secondary schools. Written informed consent was obtained from students aged 18 years and above while written informed assent was obtained from students below 18 years and school administrators.

\section{Consent for publication}

Not Applicable

\section{Availability of data and materials}

The datasets used and/or analyzed during this study are available from the corresponding author on reasonable request.

\section{Competing Interests}

The authors declare that they have no competing interests.

\section{Funding}

This research was funded by the Queen Elizabeth Commonwealth Scholarship. This funding body did not play any role in the design of the study, collection, analysis, interpretation of data and in writing of this manuscript. 


\section{Authors' contributions}

AMU designed the study, collected, analyzed, and interpreted the data and was also the major contributor in writing this manuscript. FB played a role in the design, analysis and interpretation of the data. IT designed the study, interpreted the data and also contributed in writing the manuscript. All authors read and approved the final manuscript.

\section{Acknowledgements}

The authors wish to thank Queen Elizabeth Commonwealth Scholarship and all the students and school administrators that took part in this study.

\section{References}

1. Gemma A, Corti PL, Miriam K, Joseph M. Socio Economic Effects of Gambling: Evidence from Kampala City. Uganda: Economic Policy Research Centre; 2016.

2. Press, Release, Licensed Operators 2018 [database on the Internet]. 2018. Available from: ngb.go.ug.

3. Ministry of Finance Planning and Economic Development (MFPED). The Lotteries and Gaming Bill". Bill Supplement to the Uganda Gazette No.63 Volume CVI, September 13th 2013. 2013.

4. Government of uganda. Lotteries and Gaming Government of uganda. Lotteries and Gaming. Act. 2016. In: Board LaG, editor. Kampala 2016.

5. Stucki S, Rihs-Middel M. Prevalence of adult problem and pathological gambling between 2000 and 2005: an update. J Gambl Stud. 2007;23:245-57.

6. Filipa C, Mark DG. Problem gambling worldwide: An update and systematic review of empirical research (2000-2015). J Behav Addict. 2016;5(4):592-613.

7. Nzimande S, Louw S, Mannya C. Review of the South African gambling industry and its regulation. Minister of Trade and Industry, 2010.

8. Wiebe J, Volberg R. Problem gambling prevalence research: A critical overview. Canadian gaming association, 2007.

9. Dickson L, Derevensky J. Equipping school psychologists to address another risky behavior: The case for understanding youth problem gambling. Canadian Journal of School Psychology. 2006;21(2):59-72.

10. Burnett S, Bault N, Coricelli G, Blakemore S. Adolescents' heightened risk-seeking in a probabilistic gambling task. Cogn Deviant Behaviour. 2010;25(2):183-96.

11. Fong TW. The biopsychosocial consequences of pathological gambling. Psychiatry. 2005;2(4):34.

12. Stein GN, Pretorius A, Stein DJ, Sinclair H. The association between pathological gambling and suicidality in treatmentseeking pathological gamblers in South Africa. Ann Clin Psychiatry. 2016;28(1):43-50. 
13. Blinn-Pike L, Worthy SL, Jonkman JN. Adolescent gambling: A review of an emerging field of research. J Adolesc Health. 2010;47:223-36.

14. Lee GP, Martins SS, Pas ET, Bradshaw CP. Examining potential school contextual influences on gambling among high school youth. Am J Addict. 2014;23(5):510-7.

15. Castrén $S$, Grainger $M$, Lahti $T$, Alho $H$, Salonen A. At risk and problem gambling among adolescents: a convenience sample of first-year junior high school students in Finland. Subst Abuse Treat Prev Policy. 2015;10(1):9.

16. Nowak DE, Aloe AM. The prevalence of pathological gambling among college students: a metaanalytic synthesis 2005-2013. J Gambl Stud. 2014;30:819-43.

17. Ashford L. Africa's Youthful Population: Risk or Opportunity. Washington, DC: Population Reference Bureau; 2007.

18. Abdi T, Ruiter R, Adal T. Personal, social and environmental risk factors of problematic gambling among high school adolescents in Addis Ababa, Ethiopia. J Gambl Stud. 2015;31(1).

19. Georgios DF. Gambling disorder in adolescents: prevalence, new developments, and treatment challenges. Adolesc Health Med Ther. 2018;9:43-51.

20. Delfabbro P, Lahn J, Grabosky P. Adolescent gambling in the Australian Capital Territory. Australian: Australian National University Center for Gambling Research; 2005. Available from: http://gambling.anu.edu.au.

21. Sanju G, Jaisoorya TS, Sivasankaran N, Anjana R, Priya M, Revamma M, et al. A cross-sectional study of problem gambling and its correlates among college students in South India. BJPsych Open. 2016;2:199-203.

22. Welte JW, Barnes GM, Tidwell MCO, Hoffman JH. The prevalence of problem gambling among U.S. adolescents and young adults: Results from a National Survey. J Gambl Stud. 2008;24(2):119-33.

23. Derevensky JL. Teen gambling: understanding a growing epidemic. Plymouth: Rowman \& Littlefield Publishers; 2012.

24. Reith G, Dobbie F. Beginning gambling: the role of social networks and environment. Addict Res Theory. 2011;19(6):483-93.

25. Thomas S. Parents and adolescents discuss gambling advertising: a qualitative study. Victoria: Victorian Responsible Gambling Foundation; 2014.

26. Magoon ME, Ingersoll GM. Parental modeling, attachment, and supervision as moderators of adolescent gambling. J Gambl Stud. 2006;22(1):1-22.

27. Volberg RA, Hedberg EC, Moore TL. Oregon youth and their parents: Gambling and problem gambling prevalence and attitudes. In: Services DoH, editor Oregon2008.

28. Hing N, Cherney L, Blaszczynski A, Gainsbury SM, Lubman D. I. Do advertising and promotions for online gambling increase gambling consumption? An exploratory study. International Gambling Studies [Internet]. 2014. 
29. Derevensky J, Sklar A, Gupta R, Messerlian C. An empirical study examining the impact of gambling advertisements on adolescent gambling attitudes and behaviors. International Journal of Mental Health Addiction. 2010;8(1):21-34.

30. Amani M. Implications of sports betting in Kenya: Impact of robust growth of the sports betting industry: UNITED STATES INTERNATIONAL UNIVERSITY AFRICA; 2017.

31. Williams RJ, West R, Simpson RI. Prevention of problem and pathological gambling: A comprehensive review of the evidence. In: Centre OPGR, editor. Guelph, Ontario 2008.

32. Lupu IR, Lupu V. Gambling prevention program for teenagers. Journal of Cognitive Behavioral Psychotherapies. 2013;13(2):575-84.

33. Conrad M. College Student Gambling: Examining the Effects of Gaming Education Within a College Curriculum. Massachusetts Amherst: University of Massachusetts Amherst; 2008.

34. Tolchard B, Glozah F, Pevalin D. Attitudes towards gambling in Ghanaian adolescents. 3rd International Conference and Exhibition on Addiction2014.

35. Jaisoorya T, Beena KV, Beena M, Ellangovan K, Thennarassu K, Henrietta B-J, et al. Do High School Students in India Gamble? A Study of Problem Gambling and Its Correlates. J Gambl Stud. 2017;33(2):449-60.

36. Cheung N. Low self-control and co-occurrence of gambling with substance use and delinquency among Chinese adolescents. J Gambl Stud. 2014;30(1):105-24.

37. Goldstein AL, Walton MA, Cunningham RM, Reska SM, Duan L. Correlates of gambling among youth in an inner-city emergency department. Psychol Addict Behav. 2009;23:113-21.

38. Ibáñez A, Blanco C, Donahue E, Lesieur HR, Perez de Castro I, Fernandez-Piqueras J, et al. Psychiatric comorbidity in pathological gamblers seeking treatment. Am J Psychiatry. 2001;158:1733-5.

39. Getty HA, Watson J, Frisch GR. A comparison of depression and styles of coping in male and female GA members and controls. J Gambl Stud. 2000;16:377-91.

40. Frost RO, Meagher BM, Riskind JH. Obsessive-compulsive features in pathological lottery and scratch-ticket gamblers. J Gambl Stud. 2001;17:5-19.

41. Martin JS, Usdan S, Cremeens K, Vail-Smith K. Disordered gambling and co-morbidity of psychiatric disorders among college students: an examination of problem drinking, anxiety and depression. $J$ Gambl Stud. 2014;30(2):321-33.

42. Moghaddam JF, Campos MD, Myo C, Reid RC, Fong TW. A longitudinal examination of depression among gambling in patients. J Gambl Stud. 2015;31(4):1245-55.

43. Silvia SM, Grace PL, June HK, Elizabeth L, Carla LS. Gambling and sexual behaviors in AfricanAmerican adolescents. Addict Behav. 2014;39(5):854-60.

44. Volberg R, Gupta R, Griffiths MD, Olason D, Delfabbro PH. An international perspective on youth gambling prevalence studies. International Journal of Adolescent Medicine Health. 2010;22:3-38.

45. Ministry of Education and Sports. Education Abstract 2016. In: Department EPaP, editor. Kampala: Government of Uganda; 2016. 
46. Uganda Bureau of Statistics. The National Population and Housing Census 2014 - Area Specific Profile Series-Kampala Capital City Authority. Kampala: Government of Uganda; 2017.

47. Fisher SE. Developing the DSM-IV Criteria to Identify Adolescent Problem Gambling in Non Clinical Populations. J Gambl Stud. 2000;16(2):253-73.

48. American Psychiatric Association. Diagnostic and Statistical Manual of Mental Disorders (5th edn) (DSM-5). Washington, DC2013.

49. WHO ASSIST Working Group. The Alcohol, Smoking and Substance Involvement Screening Test (ASSIST): development, reliability and feasibility. Addiction. 2002;97(9):1183-94.

50. Kessler R, editor. The WHO World Mental Health Survey: Global Perspectives on the Epidemiology of Mental Disorders: Cambridge University Press; 2008.

51. Hardoon KK, Gupta R, Derevensky JL. Psychosocial variables associated with adolescent gambling. Psychology of Addictive Behaviours Psychology of Addictive Behaviours. 2004;18(2):170-9.

52. Lund I. The population mean and the proportion of frequent gamblers: Is the theory of total consumption valid for gambling? J Gambl Stud. 2008;24(2):247-56.

\section{Supplementary Files}

This is a list of supplementary files associated with this preprint. Click to download.

- MichaeletalSTOBEchecklist.docx 